\title{
Persia, Rome and the Four Kingdoms Motif in the Babylonian Talmud
}

\author{
Geoffrey Herman
}

Apocalypses and the classical rabbinic literature are usually treated as two distinct genres with little overlap. ${ }^{1}$ While the rabbis would surely have been aware of the former, as many apocalyptic works are contemporaneous to them, the near absence of direct reference to apocalypses in their own compositions affirms their fundamentally rejectionist position with regard to this genre as a whole. The four kingdoms apocalyptic prophecy from the book of Daniel was nevertheless an important thematic construct for the rabbis. Yet, even with respect to such an apocalyptic text as this, as we shall be reminded, the rabbis have only a limited appetite. This paper will deal with the relation between Rome and Persia as perceived by the rabbis in light of this four kingdoms motif, focusing on the Babylonian rabbis and examining, in particular, a debate found in the Babylonian Talmud on whether or not Rome would ultimately subdue Persia.

The four kingdoms structure plays a major role in numerous rabbinic homilies, being linked to additional verses and subjects. For example, it is applied in the Mekhilta to non-kosher animals. In this tradition, the camel is Babylonia; the hare is Media; the rabbit is Greece and the boar is Rome. Or, alternatively, associations with the covenant of Abram are made via Gen 15:12, "As the sun was about to set, a deep sleep fell upon Abram and a great dark dread descended upon him." This verse is interpreted such that "dread" refers to the

I would like to thank Loren Stuckenbruck and Andrew Perrin for the invitation to participate in this conference and to contribute this short study to the proceedings.

1 See, for example, Shayna Sheinfeld, "The Decline of Second Temple Jewish Apocalypticism and the Rise of Rabbinic Judaism," Apocalypses in Context: Apocalyptic Currents through History, ed. Kelly J. Murphy and Justin Jeffcoat Schedtler (Minneapolis: Augsburg Fortress, 2016), 187-210; Shayna Sheinfeld, "Jewish Apocalyptic" in End of Days: An Encyclopedia of the Apocalypse in World Religions, ed. Wendell G. Johnson (Santa Barbara, CA: ABC-CLIO, 2017), 203. There are a few minor exceptions to this generalization, such as the conclusion of Mishna Sota, further expanded in the Tosefta. Although, with the early rabbinic literature focused on the law, one might wonder whether the rabbis were even conscious of this literature. Sources such as Tosefta Miqva'ot 8:6, which parodies Daniel, suggests, perhaps, an awareness of the apocalyptic texts that were presumably current at this period. 
Babylonian Empire; "dark" to Media; "great" refers to the Greek Empire; and "descended" to "the fourth empire, wicked Rome."2 In other midrashic literature the four kingdoms are connected to the four rivers coming out from Eden; the four kings with whom Abraham made war in Genesis 14; and to the covenant with Abraham. ${ }^{3}$

We frequently see the four kingdoms structure plucked from its specific historical context in the book of Daniel and grafted onto other parts of the Bible. Such instances communicate that the servitude of the people of Israel is part of the divine plan from the beginning of the Jewish nation, even from creation. ${ }^{4}$ The significance and power of the kingdoms is enlarged in the rabbinic expositions to accentuate the connection between world history and Jewish history. Ultimately, one can agree with Rivka Raviv that the notion of the four kingdoms "is transformed from a marginal idea within the Bible to a central concept in the world of the Sages. It became one of the central motifs in all of biblical commentary."

Another recent article, by Jonathan Kaplan, is devoted to the appearance of this theme in the Mekhilta de Rabbi Yishmael. ${ }^{6}$ It is noteworthy that Raviv's

2 Yithro Bahodesh, ix, Mechilta d-Rabbi Ismael, eds. H. S. Horovitz and I. A. Rabin, 2nd ed. (Jerusalem: Shalem Books, 1997), 236; J. Z. Lauterbach, ed., Mekhilta de-Rabbi Ishmael, nnd ed. (Philadelphia: The Jewish Publication Society, 2004), 339. Biblical citations are according to the NJPS (Second Edition, 1999) unless noted otherwise. All translations of rabbinic sources are my own, unless noted otherwise.

3 On the four rivers see Gen. Rab. (Theodor-Albeck edition, 146-48); and on the covenant with Abraham, see Gen. Rab. (Theodor-Albeck edition, 437). Note that for the first two items above the toponyms do not fit naturally with the kingdoms (e.g., Shinear = Greece).

4 See, for example, Gen. Rab. (Theodor-Albeck edition, 16-17):

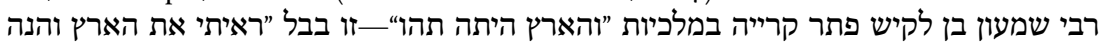

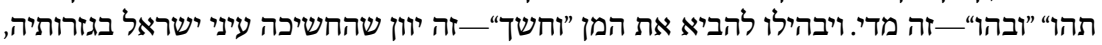

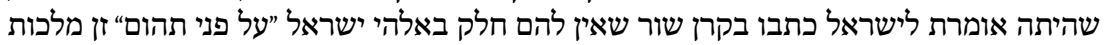

הרשעה הזו.

Translation: Rabbi Simeon the son of Laqish explained the verse as referring to the kingdoms: "The earth being unformed" - that is Babylon, "I look at the earth, it is unformed" (Jer 4:23) "and void" — that is Media, "and they hurriedly brought Haman" (Est 6:14), "with darkness" - that is Greece which darkened the eyes of Israel with its decrees, as it would tell Israel: write on the horn of an ox that they have no portion with the God of Israel, "over the surface of the deep" - that is that wicked kingdom.

5 R. Raviv, "The Talmudic Formulation of the Prophecies of the Four Kingdoms in the Book of

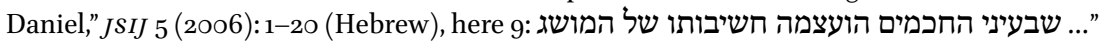

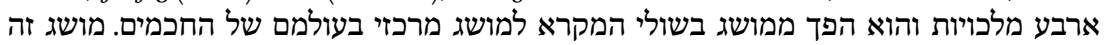

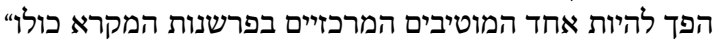

6 J. Kaplan, "Imperial Dominion and Israel's Renown: 'The Four Empires' in Mekilta de Rabbi Ishmael," in Imagination, Ideology and Inspiration, Echoes of Brueggemann in a New 
study, in practice, and Kaplan's, by design, focus on the rabbinic midrashic sources from Palestine-particularly, but not exclusively, the Mekhilta and Genesis Rabbah — with the addition of some later sources. In addition, these materials are prior to the seventh century when major political events introduced changes to the construct. Babylonian Jewish sources, however, are not considered closely or separately.

It stands to reason, of course, that the perspective of rabbis living under the yoke of "Edom," Rome, would differ to that of the rabbis living in Babylonia within a Persian realm. The question that interests me here, then, is how the rabbinic traditions from Babylonia compare with the interpretations current in the Palestinian rabbinic milieu. Did the rabbis in Babylonia see matters differently to their brethren in Palestine? I will, therefore, explore the discourse on this topic within the Babylonian Talmud, and the implicit interpretations of biblical sources that undergird this discourse.

\section{Comparing Rome and Persia}

The historical context for this question is crucial. Rome and Persia were the two superpowers of the period, poised against one another. This meant perpetual fear of conflict throughout the period in question and actual conflict a number of times in the course of the third and fourth centuries. This affected the way the rabbis read the prophecies from Daniel, as readily seen from this example found in b. Qidd. 72a as follows:

"ותלת עלעין בפומה בין שיניה" (דניאל ז, ה). אמר רבי יוחנן זו חרן הדייב ונציבין, שפעמים בולעתן ופעמים פולטתן.

"And three ribs in its mouth between its teeth" (Dan 7:5). ${ }^{7}$ Said R. Yohanan: This is Harran, ${ }^{8}$ Adiabene and Nisibis, which on occasion it swallows and on occasion it spits out.

Generation, eds. Jonathan Kaplan and Robert Williamson, Jr. (Sheffield: Sheffield Phoenix Press, 2015), 189-202.

7 My translation of the verse here differs from the JPs version.

8 This follows the version of MS Genève, Bibliothèque de Genève, Genizah 31v. For the reasons to favor this reading see Geoffrey Herman, "Babylonia of Pure Lineage: Notes on Babylonian Jewish Toponymy," in Sources and Interpretation in Ancient Judaism, ed. Meron Piotrkowsky, Geoffrey Herman, and Saskia Dönitz, AJEC (Leiden: Brill, 2018), 221-22. 
In this source, the Palestinian rabbi identifies the bear of Dan 7:5 with contemporary Persia. ${ }^{9}$ The three ribs are thus symbolically located as toponyms within the region that was the heart of ongoing conflict between the two empires. The reference provided, therefore, is specific. Historically, it corresponds reasonably with the geo-political reality that characterized the region described during the floruit of R. Yohanan, suggesting that it reflects well the period when he lived. One could say that this verse is not being read here apocalyptically. The sense is rather of an ongoing conflict between Persia and Rome that is not on the cusp of imminent resolution. ${ }^{10}$

With the very real existence of the Persian empire it was clearly not possible to imagine the four kingdoms as advancing in a chronological progression in a manner whereby one was completely replaced by the next. Persia continued to flourish, apparently with the arrival of Greece ${ }^{11}$ and Rome. And yet, the kingdoms of Babylon and Greece were gone. They must have understood the kingdoms in a dual fashion whereby there were two parallel chronological progressions, one in the East, and the other in the West. Thus, in the East, it is seen as moving from Babylonia to Persia. In the West the transition advanced from Greece to Rome. But what was expected to happen at the very end? As we will see, there was no single answer to this question.

A different impression on the relationship between Rome and Persia, however, is found elsewhere in the Babylonian Talmud. Indeed one notes that the significance of Persia for the Babylonian Talmud in the Jewish eschatological scheme is not really echoed in the Palestinian sources. The explicit question of which empire is superior, Rome or Persia, is addressed more than once in the Babylonian Talmud. Thus, in b. 'Abod. Zar. $2 b$ the two empires appear in judgement before the heavenly court. Rome appears first "since it is more important." 12 In b. Šebu. 6 b we find a conversation between Babylonian rabbis

This identification is explicit in the statement, attributed to Rav Joseph (b. Meg. 11a; b. 'Abod. Zar. 2b, and b. Yoma 77b), אלו פרסיים שאוכלין ושותין כדוב וגו ("These are the Persians who eat and drink as a bear ..."). On the angel of Persia called "Dubiel," see b. Qidd. 72b, and see further below.

10 This is essentially how the approach of R. Yohanan regarding current events is described in N. N. Glatzer, "The Attitude Towards Rome in Third-Century Judaism," in Politische Ordnung und Mentlischen Existenz, Festgabe für Eric Vögelin, ed. Alois Dempf, Hannah Arendt, and Friedrich Engel-Janosi (Munich: C. H. Beck, 1962), 243-57; N. N. Glatzer, Essays in Jewish Thought (AL: The University of Alabama Press, 1978) 1-16.

11 It is clear that they perceived the Sasanians as the same as the Persians from the period of the Bible, and not as a new kingdom.

12 The same answer is given there, with the same verse from Daniel. Persia, likened to a bear in Daniel's depiction of the four beasts, comes second. See, too, b. Git. 17a on the deliberation whether Persia is preferable to Rome. 
of the mid-fourth century. This follows an earlier attempt to explain the relationship between the signs of biblical leprosy by comparison with the relative hierarchy between government offices, and then between the Persian king and the Roman Caesar. The source is as follows:

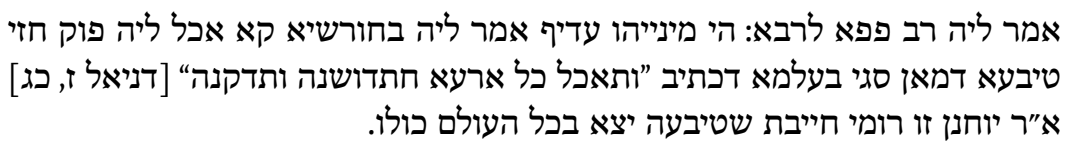

Rav Papa said to Rava: Which one is preferable? He answered him: Do you eat in a wood?!13 Go out and see whose coinage is current in the world! As it is said: "it will devour the whole earth, tread it down, and crush it" (Dan 7:23). R. Yohanan said: This is the sinful Rome whose currency has extended throughout the entire world.

The question, "which is greater?" is answered by a call to observe fiscal realitythe coinage which dominates the world. Such a "trade war" is ultimately linked to a verse taken from Daniel, reminding us to identify the contemporary powers with the allusions in Daniel, as interpreted by the third century Palestinian R. Yohanan. The hermeneutic result is achieved by transforming the crushing blow of the hooves of the fourth beast into the hammering of the mint in the production of coinage. While we are dealing with the same scriptural backdrop, and even the same R. Yohanan interpreting verses from Daniel as in the previous source, here the conclusion is different! Curiously, we have here the Babylonian Talmud citing a "Roman" rabbi affirming the superiority of Rome over Persia, at least regarding the strength of its currency. Furthermore, the scriptural support summoned here points once again not to an active apocalyptic spirit but to a considerably sublimated version of Daniel's dramatic and violent vision. ${ }^{14}$

13 On the various proposals for interpretation of the unusual expression, which I have translated, hesitantly, following Rashi's understanding, "do you eat in the woods," see the detailed discussion in Avram Israel Reisner, "On the Origins of the Sugya. Tractate Shevuot of the Babylonian Talmud-Chapter One" (PhD diss., The Jewish Theological Seminary of America, 1996), 220-23. See also Michael Sokoloff, A Dictionary of Jewish Babylonian Aramaic (Ramat Gan: Bar Ilan University Press; Baltimore: Johns Hopkins University Press, 2002), 212, who offers "perh[aps] place of sore in the eye" and translates the statement: "the place of sore in his eye is irritating him," referencing the explanation of Rav Hai Gaon.

14 This is in striking contrast to their contemporary Persian Christian author, Aphrahat. See T. D. Barnes, “Constantine and the Christians of Persia," JRS 75 (1985): 126-36. 
The most developed example in the Babylonian Talmud of the juxtaposition of Persia and Rome is a sugya in b. Yoma 1oa, that I shall first present, and then, discuss in detail: 15

ופרסאי מ"ל דמיפת קא אתו דכת' "בני יפת גמר ומגוג ומדי ויון ותובל ומשי נושי

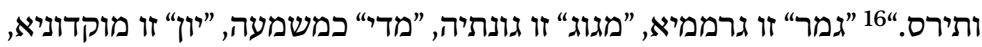

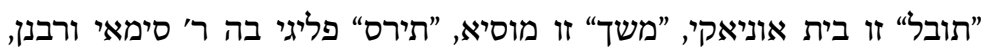

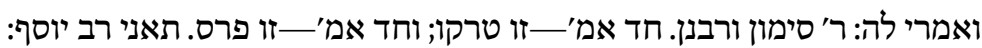

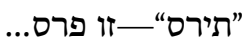
אמ'ר' יהושע בן לוי אמ' רבי: עתידה (פרס) רומי שתיפול ביד פרס, שנ' "לכן

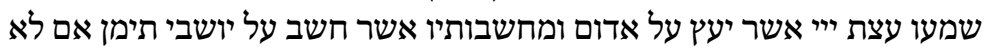

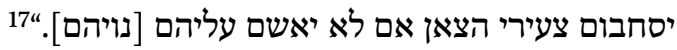

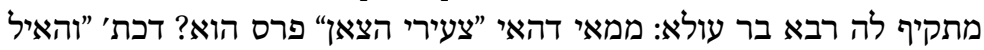

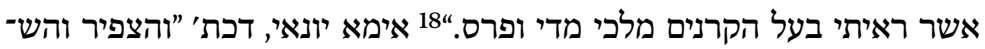

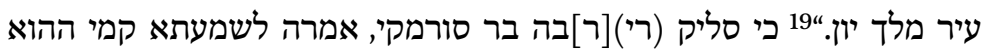

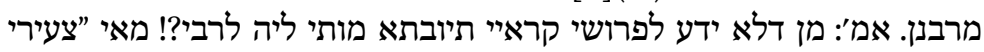

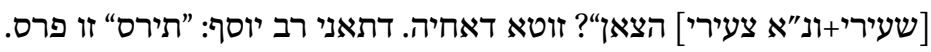

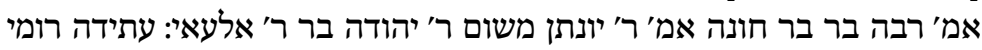

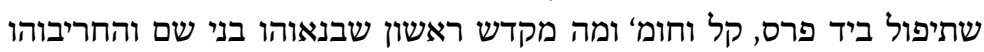
כשדיים נפלו כשדיים ביד פרסיים; מלים מקדש שנים שני שבנאוהו פרסיים שבים והחרים והחוהו רומיים לא כל שכן שיפלו רומיים ביד פריד פרסיים מקדים שים

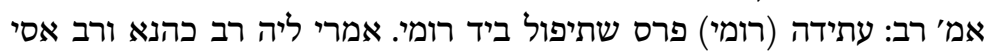

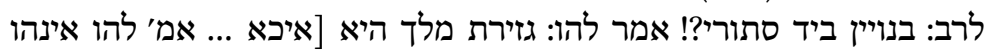

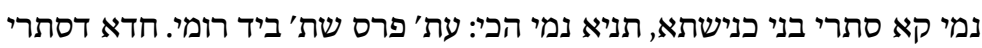

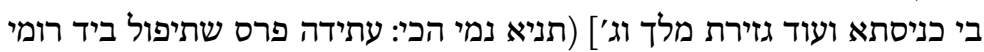
גזירת מלך) היא שיפלו בנויין ביד סתורין.

15 Cited here according to New York JTs Rab. 218 (EMC 270). I have added basic punctuation and division into sections. Square brackets indicate a gloss in the manuscript, round brackets indicate a deletion in the manuscript. The Lieberman Institute's Sol and Evelyn Henkind Talmud Text Databank lists a number of textual witnesses for this text, including genizah testimony. The main variations between the manuscript and printed versions for our purposes relate to the text in section 5, as I shall explain. My preference here for this textual witness is in light of the conclusions of Richard Kalmin ("Persian Persecution of the Jews," in Jewish Babylonia between Persia and Roman Palestine, ed. Richard Kalmin [Oxford: Oxford University Press, 2006], 125-27).

16 Gen 10:2.

17 Jer 49:20.

18 Dan 8:20.

19 Dan 8:21. 


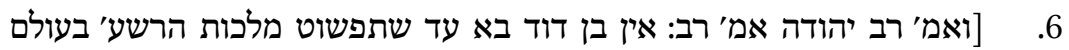

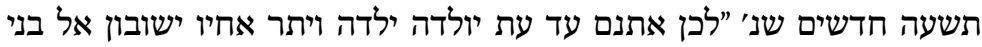

$20[$ ישראל

1. ["May God enlarge Japheth, and let him dwell in the tents of Shem" (Gen 9:27) [that means] although "God shall enlarge Japheth", the Divine Presence rests only "in the tents of Shem."] Whence do we know that the Persians are derived from Japheth?-Because it is written: "The sons of Japheth: Gomer, and Magog, and Madai and Javan, and Tubal, and Meshek, and Tiras." "Gomer" is Germania; "Magog" is Konthia; "Madai" in its literal sense; "Javan" is Macedonia; "Tubal" is Beth-Unyaqi;21 "Meshek" is Mysia; "Tiras"—its identification is a matter of dispute between R. Simai and the Rabbis, or, according to another report, between R. Simon and the Rabbis, one holding that it is to be identified with Traqu, ${ }^{22}$ and the other [authorities] declaring it is Persia. Rav Joseph learnt: "Tiras" is Persia ...

2. R. Joshua b. Levi said Rabbi said: Rome (Persia) is destined to fall through the hand of Persia, as it was said: "Hear, then, the plan which the Lord has devised against Edom, and what He has purposed against the inhabitants of Teman: surely the young of the flock $^{23}$ shall drag them away, surely their pasture shall be aghast of them." (Jer 49:20).

3. Rabbah b. 'Ullah demurred to this: What intimation is there that 'the young of the flock' refers to Persia? [Presumably] because it is written [i.e., in Scripture]: "The two-horned ram that you saw [signifies] the kings of Media and Persia." But say [perhaps] it is the Greeks, for it is written, "And the buck, the he-goat — the king of Greece?" When (Ri)[R] aba b. Surmaqi came up [i.e., to Palestine], he reported this interpretation before a certain scholar. He responded: One who does not understand the meaning of the passages of Scripture raises a challenge against Rabbi?! What does, indeed, 'the young of the flock' mean? The youngest of his brethren, for Rav Joseph learnt: Tiras is Persia.

Mic 5:2. Although the scriptural citation appears here as a scribal addition, it is included in all the other textual witnesses.

21 That is, Bithynia. For this and subsequent identifications below, see Shmuel Krauss, "Die biblische Völkertafel im Talmud, Midrasch und Targum," MGWJ 39 (1895):1-11.

22 That is, Thrace.

23 My translation of this phrase, "the young of the flock," differs from JPS, to accord better with the exegesis applied to it by the rabbis. 
4. Rabbah b. Bar Huna said R. Yohanan said, in the name of R. Judah b. Ila'i: Rome is destined to fall into the hands of Persia. That may be concluded by inference a fortiori: If in the case of the first Sanctuary, which the sons of Shem built and the Chaldeans destroyed, the Chaldeans fell into the hands of the Persians; then how much more should this be so with the second Sanctuary, which the Persians built and the Romans destroyed, that the Romans should fall into the hands of the Persians.

5. Rav said: Persia (Rome) is destined to fall through the hand of Rome. Rav Kahana and Rav Asi said to Rav: The builders in the hands of the destroyers! He responded to them: Indeed, it is a Divine decree! [There are those ... he said to them, they, too, destroy synagogues. ${ }^{24}$ We also learn thus, Persia is destined to fall by the hands of Rome, firstly, since they destroy synagogues, and furthermore, it is a Divine decree etc.] (We also learn thus: Persia is destined to fall into the hand of Rome-a Divine decree) is it that the builders should fall into the hands of the destroyers.

6. [And Rav Judah said Rav said: The son of David will not come until the evil Kingdom spreads throughout the entire world for the duration of nine months, as it is said, "Truly He will leave them [helpless] until she who is to bear has borne; then the rest of his countrymen shall return to the children of Israel." (Mic 5:2)]

My discussion of this passage begins with a structural overview. I have divided the sugya into six sections. The first section concerns the comparison between the Jerusalem temple built by Solomon and that built under the auspices of Cyrus. A scriptural verse is interpreted to indicate the inferiority of the latter. Thus, the temple constructed by "Japheth," understood as a reference to the Persians, is inferior to the one constructed by "Shem," taken as referring to the Jews. ${ }^{25}$ The association of Japheth with Persia is demonstrated scripturally, drawing support from the statement of the fourth century Babylonian rabbi, Rav Joseph. Although, this scriptural identification had been disputed in an earlier tradition that is cited. Now follows, ad loco, a detailed commentary on the table of nations from Genesis, only a small part of which I have deemed necessary to reproduce here. What I wish to note is that the identification of

\footnotetext{
24 בתי כנישתא Read.

25 Hence, Cyrus's achievement is belittled, as is the entire Second Temple period. On this trend more broadly, as reflected in rabbinic literature, see Meir Ben Shahar, "The Restoration in Rabbinic Literature: Palestine and Babylonia from Past to Present," Zion 79 (2014): 19-51 (Hebrew).
} 
the biblical nations and toponyms in the list would seem to reflect Babylonian rather than Roman traditions in many cases.

The second section transmits a declaration in the name of Palestinian rabbis, R. Joshua b. Levi in the name of Rabbi (Judah I), that Rome will be defeated by Persia, supported by the proof text from Jer 49:20.

The validity of this claim is the focus of the third section. First, it is challenged by the Babylonian Rava bar 'Ullah. He believes this interpretation is based upon assuming the "young of the flock" are Persia, as in Dan 8:20 but suggests that "young of the flock" might actually be a reference to Greece on the basis of Dan 8:21. The error of this interpretation is dramatized with a tale of a Babylonian rabbi, R. Raba b. Surmaqi, ${ }^{26}$ who went to Palestine and proposed this interpretation to a local Palestinian rabbi. He is rebutted forcefully with the assertion that he is ignorant of scriptural interpretation. The reference is to the youngest brother, that is the youngest son of the youngest of the three sons of Noah, who is understood to be Tiras. This is said to be Persia, as we have seen already, as taught by Rav Joseph.

The fourth section argues that Rome will be defeated by Persia on the basis of an a fortiori hermeneutical rule of logic and reference to the two temples. It evokes the Chasdim as well as Rome and Persia. This argument is transmitted through a chain of transmission that goes back to the tanna, R. Judah b. Ilai. ${ }^{27}$

The fifth section in the name of Rav, however, argues contrarily that Persia will be defeated by Rome. This statement is challenged by Rav's students, with an argument of logic, but rebutted with the "historiosophical" 28 response that such is a divine decree. A final note, an alternative answer, claiming that

26 This is the name according to this textual witness and JTs Rab 1623/2 (EMC 271). The others have "Haviva" (חביבא) or minor variations of it. E.g., Ms Oxford Opp. Add. 23: "Ḥaviv bar Sumaqi" (חביב בר סומקי); and Ms Munich 95 adds to the name the alliteration, "from Damascus" (מדורמסקי). This rabbinic name is mentioned only infrequently in the Babylonian Talmud. The mention in b. Meș. $85 \mathrm{~b}$ relates to the mystical. There is also uncertainty regarding his floruit. See Ch. Albeck, Introduction to the Talmud Babli and Yerushalmi, 3rd ed. (Tel-Aviv: Dvir Publishing House, 1987), 614 (Hebrew).

27 On the attitude of this tanna to Rome, see the discussion in Israel Ben-Shalom, "Rabbi Judah B. Ilai's Attitude towards Rome," Zion 49 (1984): 9-24, esp. 17 (Hebrew). Ben-Shalom argues there convincingly that the enthusiastic view of Rome, expressed by this rabbi in a source brought in b. Šhabb. 33a, is not an authentic reflection of the attitude of this rabbi, or, in fact, of any rabbi from the period immediately following the Bar-Kokhba rebellion. The tradition here, then, that attributes to R. Judah b. Ilai a prediction of Rome's defeat is not surprising. However, Rabbi Judah I also predicts the fall of Rome here. Ben-Shalom's ("Rabbi Judah B. Ilai," 17, n. 40) efforts to explain this approach despite the positive political conditions between the Jews and Rome at this time is a little weaker.

28 Cf. E. S. Rosenthal, "For the Talmudic Dictionary-Talmudica Iranica," in Irano-Judaica, Studies Relating to Jewish Contacts with Persian Culture Throughout the Ages, ed. Shaul Shaked (Jerusalem: Ben-Zvi Institute, 1982), 63. 
the Persians too are guilty since they destroy synagogues, seems to have been added to the Talmud discussion at a later time. It appears in this Talmud manuscript as a marginal gloss by another hand. Eliezer Shimson Rosenthal, as part of his own thesis, emphasized the ambiguity of this section of the tradition and its questionable association with Rav. Richard Kalmin, more recently, has argued convincingly against seeing this comment as part of the original text. ${ }^{29}$ Finally, this position regarding Rome and Persia is affirmed through the citation of another tradition in the name of Rav, understood to indicate that Rome will defeat Persia.

Taken together, we have a chiastic structure in the presentation of the positions: the assertion that Rome will be defeated is supported first by Scripture, and then with a logical argument. The assertion that Persia will be defeated is challenged by a logical inference and then affirmed by Scripture. The penultimate argument on the destroyers and builders of the temple returns us, thematically, to the opening statement which compared the builders of the two temples.

In view of the themes dealt with in this Talmudic source, and in particular, the attitudes towards Rome expressed here, the scholarly discussion on this sugya has been intense, with contributions by a number of historians of Talmudic literature, including: Jacob Neusner, Moshe Beer, E. S. Rosenthal, Isaiah Gafni, and recently, Richard Kalmin and Ron Naiweld, among others. ${ }^{30}$

29 We would then apparently have a baraita that offers both the reasons just presented as arguments why Persia will fall to Rome with a scriptural support.

30 Jacob Neusner does not analyse this passage in detail, but see, for example, J. Neusner, A History of the Jews in Babylonia: II. The Early Sassanian Period (Leiden: Brill, 1966), 44; Rosenthal, "For the Talmudic Dictionary—Talmudica Iranica," 63-64; Moshe Beer, "The Political Background of Rav's Activities in Babylonia," Zion 50 (1985):16o; M. Beer, The Sages of the Mishnah and the Talmud, Teachings, Activities and Leadership (Ramat-Gan: Bar-Ilan University Press, 2011), 15; Isaiah M. Gafni, The Jews of Babylonia in the Talmudic Era: A Social and Cultural History (Jerusalem: Zalman Shazar Center for Jewish History, 199o), 39-40; Isaiah M. Gafni, "Rabbinic Historiography and Representations of the Past," in The Talmud and Rabbinic Literature, ed. Charlotte Elisheva Fonrobert and Martin S. Jaffee, CCR (Cambridge: Cambridge University Press, 2007), 297 (= Isaiah M. Gafni, Jews and Judaism in the Rabbinic Era: Image and Reality - History and Historiography, TSAJ 173 [Tübingen: Mohr Siebeck, 2019,] 45); Kalmin, "Persian Persecution of the Jews," 121-47, esp. 122-27; and, for the first part of this source, Jason Sion Mokhtarian, Rabbis, Sorcerers, Kings, and Priests: The Culture of the Talmud in Ancient Iran (Oakland, CA: University of California Press, 2015), 68-69. See also A. H. Cutler, "Third-Century Palestinian Rabbinic Attitudes towards the Prospect of the Fall of Rome," Jss 3 (1969): 275-85; N. N. Glatzer, "The Attitude Towards Rome," 243-257; N. N. Glatzer, Essays in Jewish Thought (Tuscaloosa, AL: The University of Alabama Press, 1978), 1-16; Meir Ben Shahar, "Biblical and Post-Biblical History in Rabbinic Literature: Between the First and Second Destruction" (PhD diss., Hebrew University, 2011), 245; and the most recent exploration of this sugya by Ron 
Earlier studies sought to interpret this sugya in light of historical events and the experience of the Jews, either in Judaea or in Babylonia, under the Romans and Persians in the course of the first century of Sasanian rule. Kalmin dealt with this source in a recent study of the question of Persian persecution of the Jews under the early Sasanians. Highlighting the exegetical component, Kalmin argued that this element was not a response to current events or aspirations. In this, Kalmin's focus was on the latter part of this sugya.

What I wish to point out here, that I believe has not been addressed by earlier scholars, is the lack of correlation between what this source attributes to Palestinian rabbis, and what Palestinian rabbis are actually found saying in some rabbinic sources of Palestinian provenance.

The position that Rome will be defeated, although advanced as Palestinian, actually hinges on two points of exegesis that are vigorously associated with Babylonian interpretative preferences. Firstly, the association of Japheth with Persia, through Tiras, is Rav Joseph's statement. We also find it attested in Palestinian rabbinic sources, but there only as the minority opinion. Thus, in y. Meg. I 71b: "and Tiras"—Rabbi Simeon says: Persia; but the Rabbis say: Thrace. ${ }^{31}$ The preference for Thrace is also the view of both Josephus and Eusebius. ${ }^{32}$

The Babylonian Talmud, as we saw, does record this dispute. It recognizes that there is more than one opinion on the identification of Tiras; however, it does not know which view is held by the Palestinian rabbis as the majority view. Furthermore, despite this uncertainty, it does not treat seriously the other opinion against identifying Tiras with Persia but accepts Rav Joseph's statement concerning Tiras.

Secondly, the Babylonian Talmud tells us that the prediction that Rome will fall to Persia is the view of the Palestinian Judah I, Rabbi, on the basis of the interpretation of the verse from Jer 49:20. Palestinian sources, however, understand this verse quite differently. Genesis Rabbah interprets this same verse to mean the youngest of tribes refers to the tribe of Benjamin. ${ }^{33}$ One must

Naiweld, "The Use of Rabbinic Traditions about Rome in the Babylonian Talmud," $R H R$ 233 (2016): 255-85, esp. 264-71.

31 ותירס רבי סימון אמר פרס ורבנן אמרי תרקא:Genesis Rabbah has essentially the same text (Theodor-Albeck edition, 343): ותירס ר' סימון אמר פרס רבנין אמ' ותרבי רימון

32 Shmuel Krauss, "Die biblische Völkertafel im Talmud," 11.

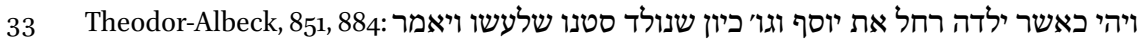

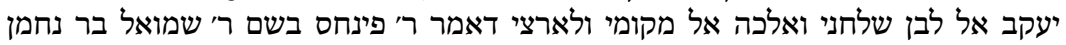

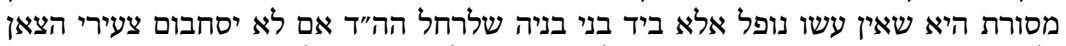

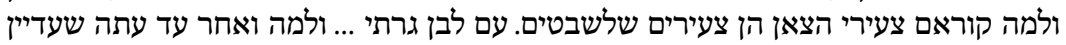

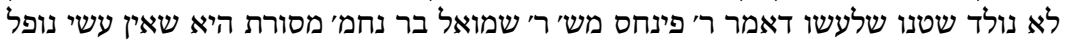
אלא ביד בני בניה שלרחל הה"ד מחיד אם לא יסחבום צחמירי מסורת הצאן צעירי שבטים עשים 
conclude, therefore, that the talmud receives a tradition that speaks of the youngest of "brothers." These "brothers" were read in the Palestinian exegetical tradition as a reference to the sons of Jacob, the tribes of Israel, but the Talmud (re-)interprets it as the youngest of the brothers who are the sons of Japheth, understood as Tiras, in turn taken as a reference to Persia. So where Palestinian rabbinic tradition imagines a final conflict between Rome and a Jewish leader from the tribe of Benjamin, the Babylonian rabbinic tradition sees a conflict between Rome and Persia.

This leads to a further noteworthy point. While this sugya is depicted as a contrast between Palestinian and Babylonian rabbinic opinion, what we see in reality is a divergence of opinion between two major rabbinic centers: Pumbedita and Sura. The first part, supporting the defeat of Rome is dependent upon the exegesis of Rav Joseph, the head of Pumbedita. The second part, supporting the defeat of Persia is explicitly in the name of the founder of the Suran rabbinic academy, Rav. This presentation of the views would seem to be a step belonging to the redactional stage of the Talmud. The question is whether or not we wish to date the individual components within this sugya to when the Rabbis named are believed to have lived.

\section{4}

\section{Conclusion}

While in Palestine the focus is on the four kingdoms as a broad idea the emphasis in Babylonia is more on the ultimate conflict between Rome and Persia and the comparison between the two. Persia has a more central role. Its conflict with Rome is treated as the penultimate stage in the four kingdoms.

The dispute presented in the Babylonian Talmud concerning whether Persia will defeat Rome or vice versa has often been treated as an expression of response to historical developments. It has been perceived as reflective of the concerns of either the Jews of Babylonia or of Palestine. In its current redacted state it would ultimately appear to be an internal dispute among Babylonian Rabbis.

The difference in opinion reflects the two rabbinic schools of Babylonia: Pumbedita in the north and Sura in the south. This is evident in both their

Translation: "And it was when Rachel begat Joseph etc." Once the adversary of Esau was born "and Jacob said to Laban: send me away and I shall go to my place and to my land." Since R. Pinhas said in the name of R. Samuel bar Nahman: It is a tradition that Esau will not fall except through the hand of the sons of the son of Rachel. As it is written: "The young of the flock will drag them away" - and why are they called "the young of the flock" - they are the youngest of the tribes. "With Laban I dwelled ..." 
traditions and outlooks. The view that Persia will defeat Rome is supported by Pumbeditan Babylonian exegetical traditions and alleges support from traditions from Palestine. The opinion that Rome will defeat Persia, asserted by rabbis of Suran provenance, is also the dominant view expressed in the Talmud's editorial layer.

\section{Bibliography}

Albeck, Chaim. Introduction to the Talmud Babli and Yerushalmi. 3rd ed. Tel-Aviv: Dvir Publishing House, 1987 (Hebrew).

Bahodesh, Yithro. Mechilta d-Rabbi Ismael. Edited by H. S. Horovitz and I. A. Rabin. 2nd ed. Jerusalem: Shalem Books, 1997.

Barnes, T. D. "Constantine and the Christians of Persia." JRS 75 (1985): 126-36.

Beer, Moshe. "The Political Background of Rav's Activities in Babylonia." Zion 50 (1985): 160.

Beer, Moshe. The Sages of the Mishnah and the Talmud, Teachings, Activities and Leadership. Ramat-Gan: Bar-Ilan University Press Ramat-Gan, 2011.

Ben Shahar, Meir. "Biblical and Post-Biblical History in Rabbinic Literature: Between the First and Second Destruction." PhD diss., Hebrew University, 2011.

Ben Shahar, Meir. "The Restoration in Rabbinic Literature: Palestine and Babylonia from Past to Present." Zion 79 (2014): 19-51 (Hebrew).

Ben-Shalom, Israel. “Rabbi Judah B. Ilai's Attitude towards Rome." Zion 49 (1984): 9-24 (Hebrew).

Cutler, A. H. "Third-Century Palestinian Rabbinic Attitudes towards the Prospect of the Fall of Rome." JSS 3 (1969): 275-85.

Gafni, Isaiah M. The Jews of Babylonia in the Talmudic Era: A Social and Cultural History. Jerusalem: Zalman Shazar Center for Jewish History, 1990.

Gafni, Isaiah M. "Rabbinic Historiography and Representations of the Past." Pages 295312 in The Cambridge Companion to the Talmud and Rabbinic Literature. Edited by Charlotte Elisheva Fonrobert and Martin S. Jaffee. CCR. Cambridge: Cambridge University Press, 2007.

Gafni, Isaiah M. Jews and Judaism in the Rabbinic Era: Image and Reality—History and Historiography. TSAJ 173. Tübingen: Mohr Siebeck, 2019.

Glatzer, Nahum N. "The Attitude Towards Rome in Third-Century Judaism." Pages 24357 in Politische Ordnung und Mentlische Existenz, Festgabe für Eric Vögelin. Edited by Alois Dempf, Hannah Arendt, and Friedrich Engel-Janosi. Munich: C. H. Beck 1962.

Glatzer, Nahum N. Essays in Jewish Thought. Tuscaloosa, AL:The University of Alabama Press, 1978. 
Herman, Geoffrey. "Babylonia of Pure Lineage: Notes on Babylonian Jewish Toponymy." Pages 191-228 in Sources and Interpretation in Ancient Judaism. Edited by Meron Piotrkowsky, Geoffrey Herman, and Saskia Dönitz. AJEc. Leiden: Brill, 2018.

Kalmin, Richard. "Persian Persecution of the Jews." Pages 121-47 in Jewish Babylonia between Persia and Roman Palestine. Edited by Richard Kalmin. Oxford: Oxford University Press, 2006.

Kaplan, Jonathan. "Imperial Dominion and Israel's Renown: 'The Four Empires' in Mekilta de Rabbi Ishmael." Pages 189-202 in Imagination, Ideology and Inspiration, Echoes of Brueggemann in a New Generation. Edited by Jonathan Kaplan and Robert Williamson, Jr. Sheffield: Sheffield Phoenix Press, 2015.

Krauss, Shmuel. "Die biblische Völkertafel im Talmud, Midrasch und Targum.” MGWJ 39 (1895): 1-11.

Lauterbach, Jacob Z., ed. Mekhilta de-Rabbi Ishmael. 2nd ed. Philadelphia: The Jewish Publication Society, 2004.

Mokhtarian, Jason Sion. Rabbis, Sorcerers, Kings, and Priests: The Culture of the Talmud in Ancient Iran. Oakland, CA: University of California Press, 2015.

Naiweld, Ron. "The Use of Rabbinic Traditions about Rome in the Babylonian Talmud." RHR 233 (2016): 255-85.

Neusner, Jacob. A History of the Jews in Babylonia: II. The Early Sassanian Period. Leiden: Brill, 1966.

Raviv, Rivka. "The Talmudic Formulation of the Prophecies of the Four Kingdoms in the Book of Daniel." JSIJ 5 (2006): 1-20 (Hebrew).

Reisner, Avram Israel. "On the Origins of the Sugya. Tractate Shevuot of the Babylonian Talmud-Chapter One.” PhD diss., The Jewish Theological Seminary of America, 1996.

Rosenthal, E. S. "For the Talmudic Dictionary-Talmudica Iranica." Pages 63-131 in Irano-Judaica, Studies Relating to Jewish Contacts with Persian Culture Throughout the Ages. Edited by Shaul Shaked. Jerusalem: Ben-Zvi Institute, 1982.

Sheinfeld, Shayna. "The Decline of Second Temple Jewish Apocalypticism and the Rise of Rabbinic Judaism." Pages 187-210 in Apocalypses in Context: Apocalyptic Currents through History. Edited by Kelly J. Murphy and Justin Jeffcoat Schedtler. Minneapolis: Augsburg Fortress, 2016.

Sheinfeld, Shayna. "Jewish Apocalyptic." Pages 200-204 in End of Days:An Encyclopedia of the Apocalypse in World Religions. Edited by Wendell G. Johnson. Santa Barbara, CA: ABC-CLIO, 2017.

Sokoloff, Michael. A Dictionary of Jewish Babylonian Aramaic. Ramat Gan: Bar Ilan University Press. Baltimore: Johns Hopkins University Press, 2002. 